Dept. of Vet. Med.,

Fac. Vet. Med., Edfina, Rashid, Alexandria Univ.

Head of Dept. M. EL-Shinnawy

\title{
AN EPIDEMIOLOGICAL STUDY ON RIFT VALLEY FEVER IN SHEEP IN EGYPT. \\ (With 5 Tables)
}

\author{
By \\ M.M. EL-SHINNAWY; N.A. HUSSEN *; M.M. EL-NIMR; \\ A.Y.A. MOHSEN $\star$; A.A. ZAGHAWA; M.S. WASSEL $* ;$ \\ E.A. EL-EBIARY* and F.F. ZAKI* \\ (Received at 26/10/1992)
}

\section{هراسة وباثية عن حمى الوادئ المتمدع في الاغخام في هصر}

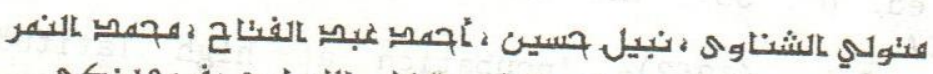

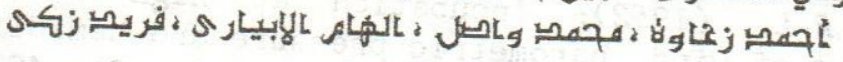

تم جمع .0rا عينة سيرم من اغنام حية و مذبوحة من محافظات القاهرة - الجيزة - الققليوبية -

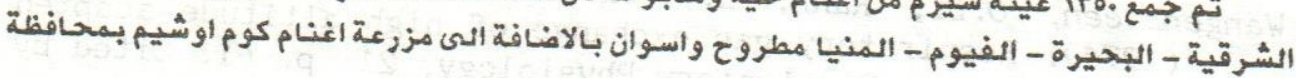
الشفيوم. فحست هذه العينات كوجود الاجسام المناعية رفيروس مرض حمى الرفت فالى باختبارات

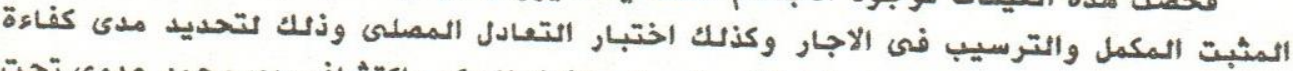

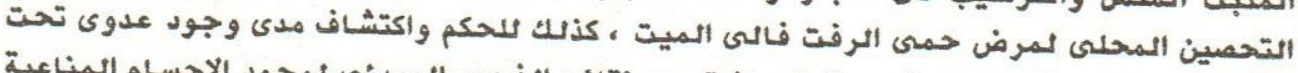

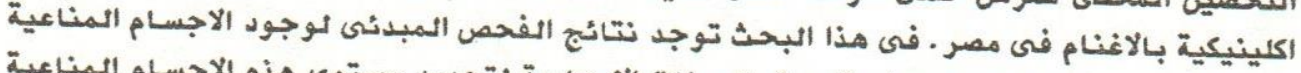

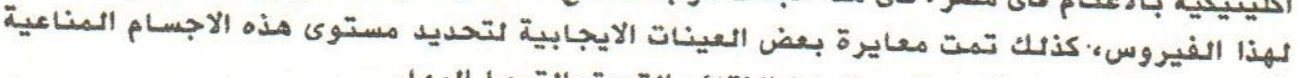

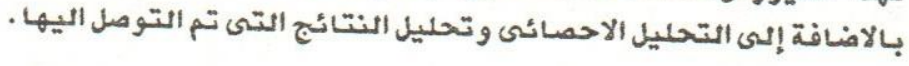

*: Serum and Vaccine Research Institute, Abbasia, Cairo, Egypt. 


\section{SUMMARY}

1350 serum samples were collected from slaughtered sheep from 9 governorates (Cairo, Giza, Qalubia, El-Sharkia, El-Behara, Fayoum, Minia, Matrouh and Aswan) as well as from 140 living sheep at kome Osheim, Fayoum province. The sera were subjected to CFT, AGPT and SNT to reveal the efficiency of the locally produced inactivted RVF vaccine in EGYPT and/or to detect the subclinical infection of RVF virus in sheep. The results of the screening with CF, AGP and SN tests as well as the titration of some positive samples with CFT and SNT are presented in this work together with its explanation and interpretation.

\section{INTRODUCTION}

Rift Valley Fever (RVF) is an acute infectious, arboviral disease affecting mainly ruminants and man, it causes a high mortality rate among animals and abortion of pregnant ones (DAUBNEY et al., 1931). It is characterized by a short incubation period, fever, leucopenia and necrotic changes in the liver.

Until 1977, RVF virus was geographically limited to subsaharan Africa. In 1977 an outbreak of RVF disease was recorded for the first time in Egypt causing high mortality and abortion rates among domestic animals with extensive human involvements (MEEGAN and MOUSSA, 1979). In this outbreak, RVF was considered to have possible origins through either importation of infected ruminants or camels from the Sudan, through infected insects carried in transportation vehicles or by wind (SELLERS et al., 1982).

The aim of this work was to investigate the immune status of sheep during the 1989-1990 where a serosurvey was done in nine governorates representing a great part of the country including the fore western governorate (Matrouh) and the fore southern one (Aswan) to clarify the immune status of animals of the Egyptian borders.

\section{MATERIAL and METHODS}

\section{1- Rift Valley Fever Virus:}

The original virus was isolated from a human patient at Zagazig, Sharkia governorate and identified as RVF virus. It was then twice passaged intra-cerebrally into suckling mice, 


\section{M.M. EL-SHINNAWY et aㅣ.}

and has a final titer of $2 \times 10^{7} \mathrm{MICID} 50 / \mathrm{ml}$.

\section{2- Cell Cultures:}

2.1 CER Cells: These cells were supplied by Wister Institute Philadelphia, USA and used for virus titration.

2. 2 BHK Cells: Baby Hamster Kidney Cells (BHK) were grown used in serum neutraliza to MACPHERSON and STOCKER (1962) and

\section{3- Sera Samples:}

A total of 1350 sheep serum samples were collected from farms and abattoirs of 9 governorates including Cairo, from Aswan. El-Sharkia, El-Beheria, Matrouh, Fayoum, Minia and sheep farm sition, 140 samples were collected from Kome Osheim inactivated alum adjuvant vacince after vaccination with RVF

\section{4- Serological Tests:}

4.1 Complement fixation test: The microtechnique of CFT was carried out according to EDWIN (1964), negative and included in the test.

4.2. Agar gel precipitation test: The antigen used was prepared in BHK cells and finally treated with Tween 80 which acts as surface agents for dispersing clumped particles. The ALLAM (1981). following the technique described by AYOUB and

\section{3 Serum neutralization test:}

The technique was that described by WALKER et al. (1970) where constant serum - virus dilution method was used. The MUENCH (1938). index was calculated according to REED and

\section{RESULTS}

\section{1- Screening of serum samples:}

The 1350 serum samples were tested serologically using CF, AGP and SN tests for the detection of antibodies against RVF province had the hgihest tables ( 1 \& 2) revealed that Matrouh AGPT and $41.3 \%$ by CFT) whilive rates ( $58 \%$ by SNT, $56.6 \%$ by having the lowest rates while the upper Egyptian provinces $22 \%$ by AGPT and SNT. From the Aswan province had $14 \%$ by CFT, tables it is obvious that results As. Vol. 28, No. 56, January 1993. 
RIFT VALLEY FEVER, SHEEP \& EGYPT

Table (1): Comparative results of different serological tests in various provinces.

\begin{tabular}{|c|c|c|c|c|c|c|c|}
\hline \multirow[b]{3}{*}{ Province } & \multirow{3}{*}{$\begin{array}{l}\text { No.of } \\
\text { rested } \\
\text { sera }\end{array}$} & \multicolumn{6}{|c|}{ Results of serological tes } \\
\hline & & CFT & $i$ & AGPT & & SNT & $6 a^{2}=3$ \\
\hline & & $\begin{array}{l}\text { No.of } \\
\text { +ve } \\
\text { samplea }\end{array}$ & $\begin{array}{l}\text { rate } \\
(\%)\end{array}$ & $\begin{array}{l}\text { No.of. } \\
\text { +ve } \\
\text { sample }\end{array}$ & $\begin{array}{l}\text { rate } \\
(\%)\end{array}$ & $\begin{array}{l}\text { No. of } \\
\text { +ve } \\
\text { sample }\end{array}$ & $\begin{array}{l}\text { race } \\
(\%)\end{array}$ \\
\hline Cairo & 150 & 25 & 16.6 & 42 & 28 & 44 & 29.3 \\
\hline Giza & 150 & 38 & 25.3 & 64 & 42.6 & 64 & 42.6 \\
\hline Qaluobia & 150 & 30 & 20 & 41 & 27.3 & 43 & 28.6 \\
\hline El-Sharkia & 150 & 48 & 32.0 & 56 & 37.3 & 56 & 37.3 \\
\hline El-Beheria & 150 & 40 & 26.6 & 61 & 40.6 & 63 & 42 \\
\hline Matrouh & 150 & 62 & 41.3 & 85 & 56.6 & 87 & 58.0 \\
\hline Fayowm & 150 & 23 & 25.3 & 31 & 20.6 & 32 & 21.3 \\
\hline Minia & 150 & 22 & 14.6 & 26 & 17.3 & 28 & 18.6 \\
\hline isswar. & 150 & 21 & 14 & 33 & 22.0 & 33 & 22.0 \\
\hline Mean results & 1350 & 309 & 22.8 & 439 & 32.5 & 450 & 33.3 \\
\hline
\end{tabular}


M.M. EL-SHINNAWY et al.

Table (2): the results of different serological tests in addition to Age and season in different provinces

\begin{tabular}{|c|c|c|c|c|c|c|c|c|c|}
\hline \multirow{2}{*}{ Province } & \multirow{2}{*}{ Season } & \multicolumn{2}{|c|}{ * Age } & \multicolumn{2}{|l|}{ CFT } & \multicolumn{2}{|c|}{ AGPT } & \\
\hline & & Grou & No. & + & - & + & - - & + & - \\
\hline \multirow{2}{*}{ Cairo } & \multirow{2}{*}{ Winter } & 1 & 118 & 19 & 99 & 31 & 87 & 33 & 85 \\
\hline & & 2 & 32 & 8 & 24 & 11 & 21 & 11 & 21 \\
\hline \multirow[t]{2}{*}{ Giza } & \multirow[t]{2}{*}{ Summer } & 1 & 97 & 22 & 75 & 37 & 60 & 37 & 60 \\
\hline & & 2 & .53 & 16 & 37 & 27 & 26 & 27 & 26 \\
\hline \multirow[t]{2}{*}{ Qaluobia } & \multirow[t]{2}{*}{ Summer } & 2 & 82 & 14 & 68 & 22 & 60 & 22 & 60 \\
\hline & & 2 & 68 & 16 & 52 & 19 & 49 & 21 & 47 \\
\hline \multirow{2}{*}{ El-Sharkia } & \multirow{2}{*}{ Summer } & 1 & 93 & 29 & 64 & 35 & 58 & 35 & 58 \\
\hline & & 2 & 57 & 19 & 38 & 21 & 36 & 21 & 36 \\
\hline \multirow[t]{2}{*}{ El-Beberia } & \multirow[t]{2}{*}{ Summer } & 1 & 117 & 32 & 85 & 49 & 68 & 51 & 66 \\
\hline & & 2 & 33 & 8 & 25 & 12 & 21 & 12 & 21 \\
\hline \multirow[t]{2}{*}{ Matroub } & \multirow[t]{2}{*}{ Summer } & 1 & 79 & 29 & 50 & 42 & 37 & 44 & 35 \\
\hline & & 2 & 71 & 33 & 38 & 43 & 28 & 43 & 28 \\
\hline \multirow[t]{2}{*}{ Fayoum } & \multirow[t]{2}{*}{ Winter } & 1 & 85 & 13 & 72 & 17 & 68 & 17 & 68 \\
\hline & & 2 & 65 & 10 & 55 & 14 & 51 & 15 & 50 \\
\hline \multirow[t]{2}{*}{ Minia } & \multirow[t]{2}{*}{ Winter } & 1 & 82 & 12 & 70 & .13 & 69 & 15 & 67 \\
\hline & & 2 & 68. & 10 & 58 & 13 & 55 & 13 & 55 \\
\hline \multirow[t]{2}{*}{ Aswan } & \multirow[t]{2}{*}{ Winter } & 1 & 58 & 8 & 50 & 12 & .46 & 12 & 46 \\
\hline & & 2 & 92 & 13 & 79 & 21 & 71 & 21 & 71 \\
\hline
\end{tabular}

* Age: group 1: means lower than 2 years

2: means bigher than 2 years. 
of AGP and SN tests are quite similar to each other. It is also evident that the rates detected by both tests are much higher than the analogous rates detected by the CF test.

\section{2- RVF virus isolation:}

Under the conditions of the present field investigation, no virus could be isolated from all the serum samples collected in this study.

3- Quantitative test on positive screened serum samples:

The results of quantitative CFT (Table 3 ) revealed that the titer of CF antibodies ranged between $8-32$ and in some cases 64 especially in Matrough province. The results of quantitative SNT on some positive sera had an index higher revealed that at least $50 \%$ of the from 2.2 up to 3.5 were noticed in all tested sera from Matrouh province.

4- Results of Kome Osheim farm:

Due to the insufficient data about the vaccination of the 1350 sheep examined above, a sheep farm (Kome Osheim farm at Fayoum province) was selected where animals are vaccinated to study the immune response of the tests shown in table (5) results of different serological tes of lambs of less than indicated that in non vaccinated group of lambs of lest virus months old, $20 \%$ of its samples had antibodies agd not possess while lambs of more than 2 months second group ( 2 months antibodies against RVF virus. In gel vaccine), the rate of post-vaccination with RV positive cases ( $\mathrm{months}$ post-vaccination), the rate of positive cases declined reaching $11.6 \%$ by CFT, $16.6 \%$ by AGPT and $21.6 \%$ by SNT.

\section{DISCUSSION}

Since the last epizootic of RVF in Egypt 1977, strict quarantine measures and vaccination programmes were adapted by the Veterinary Service Organization using a locally produced tissue culture inactivated vaccine produced at Abbassia, Cairo (EL-MIMR, 1980). It is important to follow the immune status of sheep to determine the efficiency of the little work was done programmes. Since the lastest investigation was carried out in the east part of delta at Dakahiliya governorate (BOTROS et

Assiut Vet. Med. J. Vol. 28, No. 56, January 1993. 
M.M. EL-SHINNAWY et al.

Table 3

Quantitative results of comploment fixation test on sera samples fr omvarious provinces

\begin{tabular}{|c|c|c|c|c|c|c|}
\hline \multirow[t]{2}{*}{ province } & \multirow{2}{*}{$\begin{array}{l}\text { Number of } \\
\text { positive ser a }\end{array}$} & \multicolumn{4}{|c|}{ Titar of CFT $(1 / x)$} & \multirow[b]{2}{*}{64} \\
\hline & & 4 & 8 & 16 & 32 & \\
\hline Catiro & 25 & 2 & 11 & 7 & 4 & 1 \\
\hline Cizid & 38 & 5 & 14 & 10 & ส & 3 \\
\hline Qaluobia & 30 & 1 & 12 & 11 & 4 & 2 \\
\hline Watrouh & 62 & 5 & 18 & 21 & 11 & 7 \\
\hline El-Sharkia & 48 & 4 & 18 & 18 & 9 & 1 \\
\hline E1-Beheria & 10 & 2 & 13 & 16 & 8 & 2 \\
\hline Fayoun & 23 & 4 & 8 & 8 & 3 & - \\
\hline Minia & 22 & 5 & 7 & 6 & 3 & 1 \\
\hline Aswatn & 21 & 4 & 9 & 7 & 1 & - \\
\hline
\end{tabular}

Asslut Vet. Med. J. Vol. 28, No. 56, January 1993. 
RIFT VALLEY FEVER, SHEEP \& EGYPT

Table 4

Quantitative results of serum neutralization test on some selected sera samples from various provinces

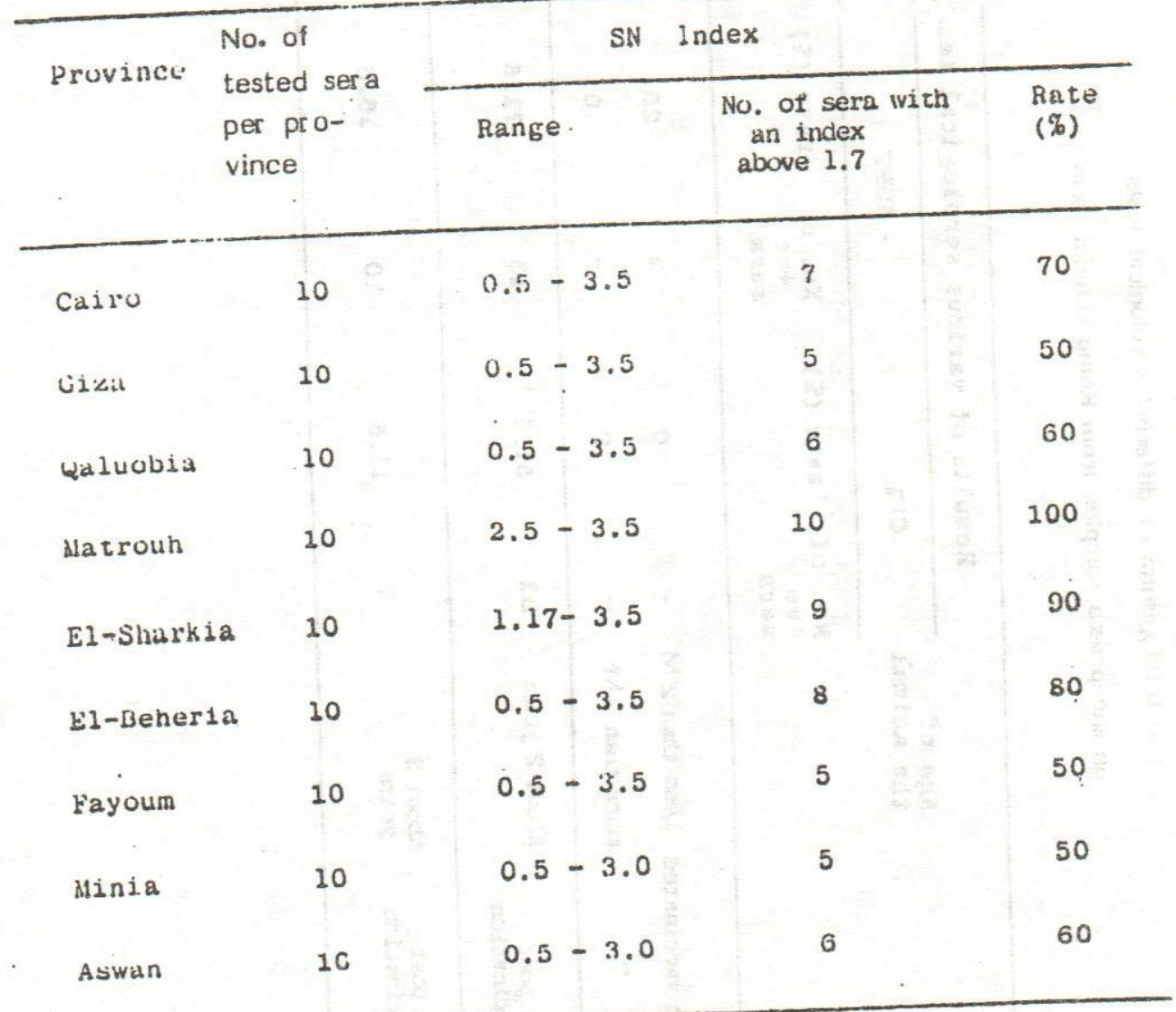


M.M. EL-SHINNAWY et al.

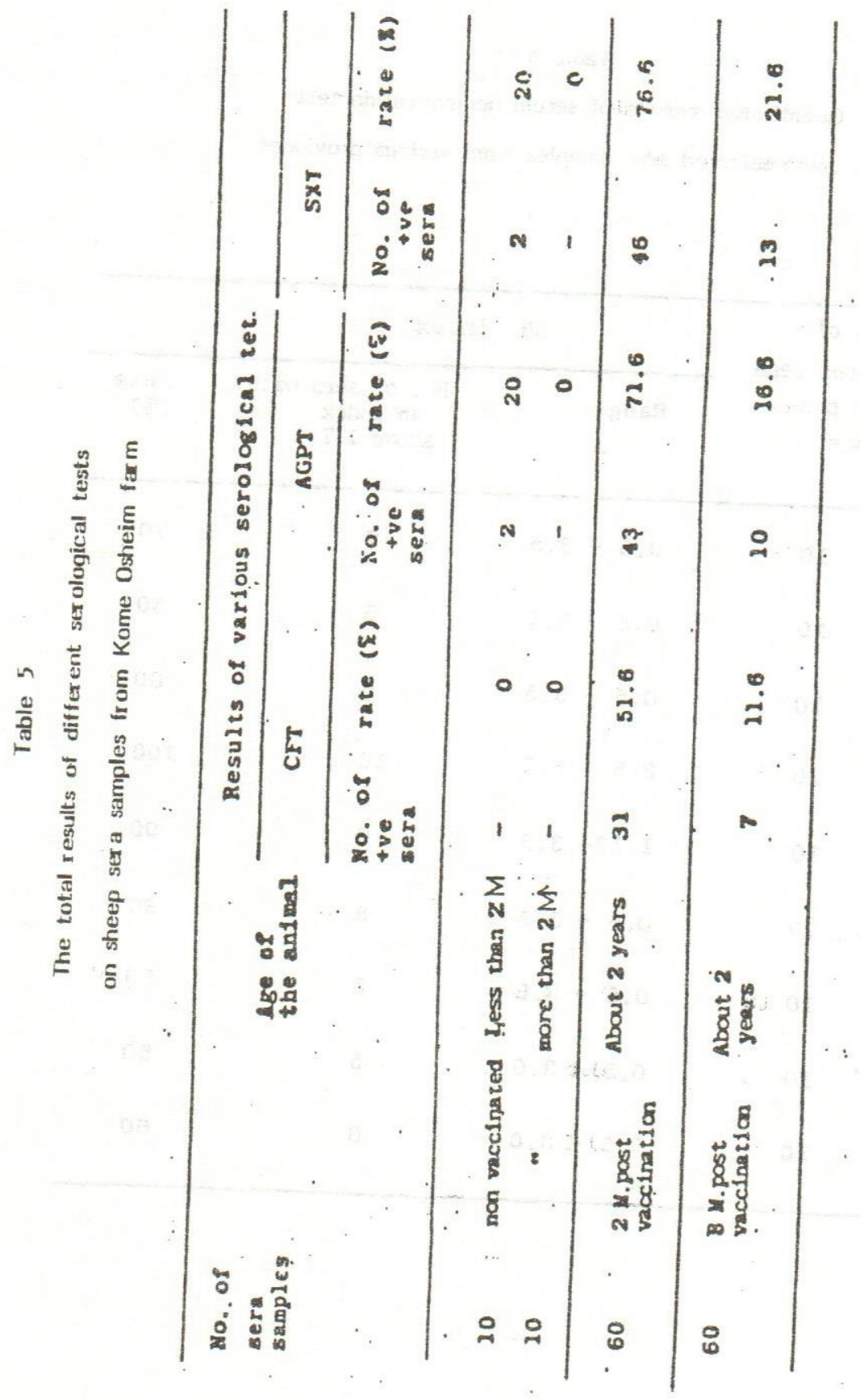




\section{M.M. EL-SHINNAWY et al.}

al. , 1989). The present results of screening of serum samples from the selected governorates showed that Matrouh province has the highest positive rates with all serological tests $(41.3 \%$ by CFT, $56.6 \%$ by AGPT and $58 \%$ by SNT). While Minia and Aswan had low titers of antibodies. Statistical analysis of these results showed that Matrough province had a significantly higher rate in different serological tests than other provinces. The cause may be attributed to either efficient vaccination programmes or due to a sort of subclinical infection with RVF virus or other antigenically related viruses as phlebotomus virus; a matter which cannot be settled unless further investigations are done. However, the low percentage of postiive sheep sera in other However, the
provinces which was mostly below $30 \%$ would give indication for
irregular or infficient vaccination programmes applied in these provinces (especially in Minia and Aswan). From statistical analysis, by applying CHI square method, these was no significant effect of age in different provinces. On the other hand, there was a significant effect of summer season gave higher positive rates than those collected during the winter season. This is due to the prevalence of Culex pipens during summer months which is the main vector in the transmission of RVF in Egypt as recorded by MEEGAN et al. (1980). The results of quantitive CFT revealed that most of sera examined in this study had a low level of antibodies indicting that this test is not as efficient as the other tests. However, using the quantitative SNT, more than $50 \%$ of tested be considered protective index higher than 1.7 which would be considered protective (randell ET AL., 1962). higher sn indices ranging from 2.2 up to 3.5 were noticed in all sera tested from Matrouh province which might be either due to recent vaccination or exposure of the animals to infection as suggested been the results of the CF test on one hand and those of the AGP and SN tests on the other hand may be attributed to that the latter two tests could detect the presence of a small amount of antibodies where as the CF test could not.

Serological results obtained from Kome Osheim farm showed that no antibodies could be detected in non vaccinated group except in two cases of less than 2 months old tested by AGP and SN tests which might mainly be due to residual maternal immunity. Such finding is in agreement with those results obtained by REDA et al. (1987). Sheep sera collected 2 months post vaccination showed better immune response than those obtained from 8 months post vaccination with RVF vaccine. From Assiut Vet. Med. J. Vol. 28, No. 56, January 1993. 
these results it is concluded that a booster dose of the suggested before by $E L-N I M R$ months post vaccination which was (1980).

As regards the sensitivity tests it was found that AGPT was of the applied serological used for screening serum samples. nearly as good as SNT when be the findings of SWANEPOE . These results are supported precipitation lines 6 days after et al. (1986) who detected reported that SNT was more sensitive initial vaccination and and WALKER (1980) reached sensitive than CFT. Besides SHOPE considered SNT as the most the same conclusion since they evaluate the immune status of anific and recommended test to Due to the insufficient animals against RVF virus.

vaccination programmes, one cannot lable information about the the epidemiology of RVF virus deduce a clear picture about attention sould be directed towardsection in sheep. However borders specially those of the souts governorates at Egyptian close to Sudan where the disease is area would create at least a buffer known to be enzootic, such of the disease to our country in for preventing the entry

\section{REFEERENCES}

Ayoub, N.N. and Allam, I.H. (1981): The immune diffusion test in RVF. J. Egypt Public Health Assoc.; LVI: 454-462. Soliman, A.K.; Scott, R.Mc. Morrill, J.C.; Salib, A.W.; Valley Fever in Egypt 1986 and Barakat, A. (1988): Rift grazing in the North East Nirveillance of sheep flocks Hygiene 91: 183-188. East Nile Delta. J. of Trop. Med. and Daubney, $R$. Hudson, $J$

Fever or Enzootic Hepatitis.ham, P.C. (1931): Rift Valley

Edwin, H.L. (1964): Complement fixation. Bact. 43: 345-379. Microtechique) Diagnostic procedure for

rickettsial disease $4^{\text {th }}$ Ed. p. $52-58$ and $317-323$.
El-Nimr, M.M. (1980): Studies on the inal and against RVF. Ph.D. Thesis on the inactivated vaccine Assiut University.

Harrrington, D.G; Lup Reynolds, J.A. and Slone.; Crabbc. L.; Peter, C.L.; formalin inactivated RVF vaccine (1980): Evaluation of Res., 10: 1559-1564. 
M.M. EL-SHINNAWY et $\underline{\text { al. }}$. Macpherson, I.A. and Stocker, M.G.P. (1962): Polyoma
transformation of hamster cell clones. An investigation of genetic factor affecting cell competence. Virology 1: 147.

Meegan, J.M.H. and Moussa, M.I. (1979): An epizootic of RVF in Egypt in 1977. Vet. Rec. 105: 124-125.

Meegan, J.M.H.; Kholil, G.M.; Hoogstrall, H. and Adham, F.K. (1980): Experimental transmission and field solution. Studies implicating Culex pipens as a vector of RVF virus in Egypt. Amer. J. Trop. Med. Hyg., 29: 1405-1410.

Ranad11, R.; Gibbs, C.J.; Aulisio, C.G.; Binn, L. and Nand Harrison, V.R. (1962): The development of a formalin Killed RVF vaccine for use in man. J. Imm. 89: 660-671.

Reda, I.M.; Saber, M.S.; Mohsen, A.Y.A.; E1-Nimr, M.M.; Assad, S. and Taha, M. (1987): Maternal immune response transferred from bovine vaccinated with inactivated RVF vaccine. Assiut Vet. Med. Journal 18(36): 95-100.

Reed, L.J. and Muench, H. (1938): Simple method of estimating $50 \%$ end points. Am. J. Hyg., 27: 493-497.

Sellers, R.F.; Peolyley, D.E. and Tucken, M.R. (1982): Rift Valley Fever, Egypt 1977; disease spread by windborne insect vectors. Vet. Rec., 110: 73-77.

Shope, R.E. and Walker, J.S. (1980): Serological relationship between RVFV and Viruses of the phlebotomus fever serogroup. Lancet I. (8178): 883-887.

Smithburn, K.C.; Mahaffy, A.F.; Haddow, A.J.; Kitchem, S.F. and Smith, J.F. (1949): RVF accidental infection among laboratory worker. J. Imm., 62: 213-227.

Swanepoel, R.; Struthers, J.K.; Erasmus, M.J.; Shepherd, S. and Megillivray, G.M. (1986): Comparison of techniques for demonstrating antibodies to RVF virus. Journal of Hygiene of Hygiene, 97: 317-329.

Walker, J.S.; Remmela, N.S.; Carter, R.C.; Mitten, J.O.; Schuh, L.G.; Stephen, c.L. and Klein, F. (1970): The clinical aspect of RVF virus in household pets. I. susceptibility of the dog. J. Inf. Dis., 121: 9-18.

Assiut Vet. Med. J. Vol. 28, No. 56, January 1993. 